\title{
Aluminum-phthalocyanine chloride associated to poly(methyl vinyl ether-co-maleic anhydride) nanoparticles as a new third-generation photosensitizer for anticancer photodynamic therapy
}

This article was published in the following Dove Press journal:

International Journal of Nanomedicine

7 March 2014

Number of times this article has been viewed

Luis Alexandre Muehlmann*

Beatriz Chiyin Ma*

João Paulo Figueiró Longo

Maria de Fátima Menezes

Almeida Santos

Ricardo Bentes Azevedo

Department of Genetics and Morphology, Institute of Biological Sciences, University of Brasília, Brasília/DF, Brazil

*These authors contributed equally to this work
Correspondence: Ricardo Bentes Azevedo

Departamento de Genética e Morfologia, Instituto de Ciências Biológicas Campus Darcy Ribeiro, CEP 70910-000,

Brasília, Distrito Federal, Brazil

Tel +55 6I3 3072 I69, +55 6I8 I| 29563

Email razevedo@unb.br

\begin{abstract}
Photodynamic therapy is generally considered to be safer than conventional anticancer therapies, and it is effective against different kinds of cancer. However, its clinical application has been significantly limited by the hydrophobicity of photosensitizers. In this work, a system composed of the hydrophobic photosensitizer aluminum-phthalocyanine chloride (AlPc) associated with water dispersible poly(methyl vinyl ether-co-maleic anhydride) nanoparticles is described. AlPc was associated with nanoparticles produced by a method of solvent displacement. This system was analyzed for its physicochemical characteristics, and for its photodynamic activity in vitro in cancerous (murine mammary carcinoma cell lineage 4T1, and human mammary adenocarcinoma cells MCF-7) and noncancerous (murine fibroblast cell lineage NIH/3T3, and human mammary epithelial cell lineage MCF-10A) cell lines. Cell viability and the elicited mechanisms of cell death were evaluated after the application of photodynamic therapy. This system showed improved photophysical and photochemical properties in aqueous media in comparison to the free photosensitizer, and it was effective against cancerous cells in vitro.
\end{abstract}

Keywords: third-generation photosensitizer, nanoparticles, cancer, photodynamic therapy, drug delivery systems

\section{Introduction}

Photodynamic therapy (PDT) has been shown to be effective against different types of cancer. ${ }^{1,2}$ It is based on the combination of two separately innocuous components, light and a photosensitizer (PS), inside a biological target. ${ }^{3}$ Basically, the target is first exposed to the PS and then irradiated with light at a wavelength intensely absorbed by the PS, but which is poorly absorbed by biological structures. ${ }^{3-5}$ Once the PS absorbs light, reaching an excited state, it can emit fluorescence or phosphorescence, it can react with different surrounding molecules, generating radicals - type 1 photoreaction - or it can catalyze the conversion of triplet oxygen $\left({ }^{3} \mathrm{O}_{2}\right)$ into singlet oxygen $\left({ }^{1} \mathrm{O}_{2}\right)$ - type 2 photoreaction. ${ }^{3,4}$ The oxidative burst generated by these photoreactions can induce stress and/or death by apoptosis or necrosis in the target cell. ${ }^{6}$ However, despite the encouraging results obtained so far with anticancer PDT, an ideal PS has not been found. ${ }^{1,3,7}$

The first-generation porphyrinoid PSs are the ones most used in clinical anticancer PDT. However, they present important drawbacks such as absorption 
of light at relatively short wavelengths, low extinction coefficients, and induction of prolonged skin photosensitization (1-2 months). ${ }^{1,7,8}$ Improved, second-generation PSs have been developed over the last few decades. ${ }^{1,7}$ Among these second-generation PSs, phthalocyanine derivatives have attracted considerable attention, mainly because they present some optimal characteristics for anticancer PDT, such as absorption of light at 660-770 nm, high quantum yield for the generation of singlet oxygen, and rapid, prolonged accumulation inside cancerous cells. ${ }^{7-9}$ However, most phthalocyanine derivatives exhibit high hydrophobicity, which limits their clinical efficacy for different reasons, such as the loss in photodynamic activity, ${ }^{10}$ or the pharmacokinetic issues that may arise from molecule aggregation, such as poor tissue distribution, hampering intravenous use. ${ }^{9}$

Hydrophobic phthalocyanine derivatives aggregate in aqueous media, undergoing self-quenching, a phenomenon that drastically reduces the photodynamic activity of the PSs, ie, their capacity to produce reactive species by photoreactions. ${ }^{11}$ In this context, the association of hydrophobic PSs to water-dispersible drug nanocarriers has been suggested as a solution to the aggregation issue. ${ }^{12-16}$ This approach also presents the advantage of allowing tumors to be targeted by passive and active strategies. ${ }^{12,17,18}$ This kind of system, in which the PS is associated to carriers, is often referred to as third-generation PS. ${ }^{19}$ In this context, in recent years, poly(methyl vinyl ether-co-maleic anhydride) (PVM/MA) has been reported to be a good candidate for composing versatile, biodegradable, water-dispersible drug nanocarriers. ${ }^{20-23}$ In the present work, PVM/MA nanoparticles (NPs) were used as water-dispersible carriers for aluminum-phthalocyanine chloride (AlPc). This new third-generation PS system showed improved photophysical properties in aqueous media and photodynamic activity in vitro against cancerous cells.

\section{Materials and methods}

\section{Chemicals and cells}

PVM/MA (Gantrez ${ }^{\circledR}$ AN-119) was kindly gifted by ISP Corporation (São Paulo, São Paulo, Brazil). Dulbecco's Modified Eagle's Medium (DMEM) (HyClone ${ }^{\text {TM; }}$ Thermo Fisher Scientific, Waltham, MA, USA). Penicillin, streptomycin, and fetal bovine serum (Gibco ${ }^{\circledR}$; Life Technologies, Carlsbad, CA, USA). Phosphate buffered saline (PBS) (Laborclin produtos para laboratórios Ltda, Pinhais, Paraná, Brazil). Dimethyl sulfoxide, acetone, ethanol (Vetec Química Fina Ltda, Xerém, Rio de Janeiro, Brazil). All other materials were purchased from Sigma-Aldrich (St Louis, MO, USA). The cell lineages used included: murine mammary carcinoma cell lineage 4T1 (kindly provided by Dr Suzanne Ostrand-Rosenberg; MD, USA); human mammary adenocarcinoma cells MCF-7; murine fibroblast cell lineage NIH/3T3 (Rio de Janeiro Cell Bank [RJCB], Rio de Janeiro, Brazil); and human mammary epithelial cell lineage MCF10A (kindly provided by Dr Maria Mitzi Brentani, University of São Paulo, São Paulo, Brazil).

\section{Production of PVM/MA particles by solvent displacement}

PVM/MA particles were obtained through a solvent displacement method based on a previously described protocol. ${ }^{24}$ Briefly, PVM/MA was dissolved in acetone at concentrations of $10 \mathrm{mg} / \mathrm{mL}, 20 \mathrm{mg} / \mathrm{mL}, 30 \mathrm{mg} / \mathrm{mL}, 40 \mathrm{mg} / \mathrm{mL}, 60 \mathrm{mg} /$ $\mathrm{mL}$, and $80 \mathrm{mg} / \mathrm{mL}$. Next, $10 \mathrm{~mL}$ of ethanol and $10 \mathrm{~mL}$ of distilled water were added, in that sequence, to $5 \mathrm{~mL}$ of each PVM/MA solution, under mild stirring at room temperature. Stirring was continued for 10 minutes, and then the organic solvents were removed by distillation at $45^{\circ} \mathrm{C}$ under reduced pressure (80 mbar) in a rotavapor apparatus (Rotavapor ${ }^{\circledR} \mathrm{R} \mathrm{II}$; BÜCHI Labortechnik AG, Flawil, Switzerland). The volume of the aqueous dispersion was then completed to $10 \mathrm{~mL}$ with distilled water and centrifuged at 22,000 $\times g$ for 30 minutes. The fully transparent supernatant was removed and the pellet was resuspended in $5 \mathrm{~mL}$ of distilled water. This dispersion was immediately analyzed for its colloidal characteristics.

\section{Colloidal characterization}

The hydrodynamic diameter (HD) and zeta potential of NPs dispersed in $\mathrm{PBS}$ were measured at $25^{\circ} \mathrm{C}, \mathrm{pH} 7.4$, by photon correlation spectroscopy and electrophoretic laser Doppler velocimetry (Zetasizer Nano ZS; Malvern Instruments, Malvern, UK), respectively. The polydispersity index (PDI) was calculated by the equipment software from dynamic light scattering measurements. All measurements were performed in triplicate and the results are presented as mean \pm standard error of the mean (SEM).

\section{Effect of Tween ${ }^{\circledR} 20$ on AIPc aggregation}

Molecular aggregation impairs the photodynamic efficiency of a PS and, thus, must be avoided. ${ }^{16}$ This phenomenon is observed for hydrophobic phthalocyanines, such as AlPc, in aqueous media. ${ }^{9}$ Therefore, the biocompatible surfactant Tween $^{\circledR} 20$ was added to the precipitation medium to reduce the aggregation of AlPc during and after its incorporation to PVM/MA NPs. 
Different concentrations of Tween 20 were tested. Briefly, $28 \mathrm{~mL}$ of ethanol and $21 \mathrm{~mL}$ of distilled water were added, in that sequence, under mild stirring, at RT, to $14 \mathrm{~mL}$ of a $20 \mathrm{mg} / \mathrm{mL}$ PVM/MA acetone solution. Then, seven aliquots of $9 \mathrm{~mL}$ were separated; Tween 20 was added in different amounts and the volume of each aliquot was completed to $10 \mathrm{~mL}$ with distilled water. The final concentrations of Tween 20 ranged from $0 \%-2 \%$ (w:v). Next, $350 \mu \mathrm{L}$ of $300 \mu \mathrm{MAlPc}$ in ethanol was added dropwise to each aliquot under mild stirring. Organic solvents were removed, as described before; the dispersions were washed twice with $4 \mathrm{~mL}$ of distilled water $(22,000 \times g$ for 30 minutes $)$ and the NPs were then redispersed in $2 \mathrm{~mL}$ of distilled water. The concentration of AlPc was measured as described below. Dispersions were then diluted in distilled water to $1 \mu \mathrm{MAlPc}$, and fluorescence intensity (excitation [ex] $\lambda 350 \mathrm{~nm}$, emission [em] $\lambda 690 \mathrm{~nm}$ ) was measured in triplicate with a spectrofluorophotometer. The result was expressed as the normalized mean \pm SEM of the fluorescence quantum yield $(\Phi F)$.

\section{Measurement of AIPc concentration}

Samples were diluted 20-fold in ethanol 99\%, left at RT for 30 minutes, and the fluorescence intensity (ex $\lambda 350 \mathrm{~nm}$, em $\lambda 680 \mathrm{~nm}$ ) was then read with a spectrofluorophotometer. The concentration of AlPc was calculated on the basis of the measured fluorescence intensity with the equation of the standard curve obtained with AlPc in ethanol 95\% $\left(r^{2}>0.999\right.$, in the range of $0.15-5.0 \mu \mathrm{M} \mathrm{AlPc}$ ).

\section{Effect of AIPc concentration on AIPc aggregation and on its efficiency of association to PVM/MA nanoparticles}

Dispersions of PVM/MA NPs were prepared as described before, with $20 \mathrm{mg} / \mathrm{mL}$ of PVM/MA in acetone. To $5 \mathrm{~mL}$ aliquots of this dispersion, $500 \mu \mathrm{L}$ of AlPc in ethanol, at concentrations ranging from $12-384 \mu \mathrm{M}$, were dropwise added under mild stirring and RT. Then, samples were left under stirring for 10 minutes, organic solvents were removed, the NPs were washed twice with $2 \mathrm{~mL}$ of distilled water, and they were resuspended in $0.5 \mathrm{~mL}$ of distilled water. The concentration of AlPc was measured as described before, and the dispersions were then diluted with water to $1 \mu \mathrm{M}$ AlPc. The absorption spectrum and fluorescence intensity (ex $\lambda 350 \mathrm{~nm}$, em $\lambda 690 \mathrm{~nm}$ ) of each sample were measured with a spectrofluorophotometer. AlPc association efficiency was calculated as the percentage of AlPc remaining in the final dispersion in relation to the initially added amount. The $\Phi F$ was normalized and expressed as the mean \pm SEM.

\section{Association of AIPc to PVM/MA nanoparticles}

The procedures described above led to the establishment of a standard protocol for associating AlPc to PVM/MA NPs. Throughout the following text, the NPs obtained by this protocol are referred to as AlPc-NP.

AlPc-NP was prepared by adding $10 \mathrm{~mL}$ of ethanol, $7.5 \mathrm{~mL}$ of distilled water, and $2.5 \mathrm{~mL}$ of $15 \%$ (w:v, in water) Tween 20, in that sequence, to $5 \mathrm{~mL}$ of $20 \mathrm{mg} / \mathrm{mL}$ of PVM/ MA in acetone, under mild stirring at RT. Next, $833 \mu \mathrm{L}$ of $300 \mu \mathrm{M}$ AlPc in ethanol were added dropwise, and the dispersion was continued under mild stirring for 10 minutes at RT. The organic solvents were then removed by distillation at $45^{\circ} \mathrm{C}$ under reduced pressure $(80 \mathrm{mbar})$ in a rotavapor apparatus; the volume of the remaining aqueous dispersion was completed to $10 \mathrm{~mL}$ with distilled water and this NP dispersion was washed twice $(22,000 \times g$ for 30 minutes $)$ with distilled water. Finally, the NPs were resuspended in $5 \mathrm{~mL}$ of PBS or distilled water; a $50 \mu \mathrm{L}$ aliquot was separated for characterization, and the remaining volume was kept frozen at $-20^{\circ} \mathrm{C}$ until usage. Pure PVM/MA NPs were prepared through the same protocol, without AlPc.

\section{Scanning electron microscopy}

The shape and surface morphology of NPs were both investigated in a field-emission scanning electron microscope (JSM7001F; JEOL, Tokyo, Japan). Briefly, $20 \mu \mathrm{L}$ of AlPc-NP dispersed in water were deposited on copper supports. Next, the sample was left to dry for 5 hours at room temperature in a jar containing silica gel desiccant, and then coated with gold using Blazers SCD $050^{\circledR}$ sputter coater (Blazers Union AG, Fürstentun, Liechtenstein). The images were digitalized using an UltraScan ${ }^{\mathrm{TM}}$ camera connected to DigitalMicrograph ${ }^{\mathrm{TM}}$ 3.6.5 computer software (Gatan, Inc., Pleasanton, CA, USA).

\section{Photophysical characterization}

Fluorescence and absorption spectra, optical density, turbidity, and fluorescence intensity, in the visible region of the electromagnetic spectrum, were all measured in a spectrofluorophotometer (Spectramax ${ }^{\circledR}$ M2; Molecular Devices LLC, Sunnyvale, CA, USA) at $25^{\circ} \mathrm{C}$.

\section{Infrared spectroscopy}

Ten milliliters of AlPc-NP dispersed in water were prepared, as described before, and separated into two aliquots. A $5 \mathrm{~mL}$ aliquot was immediately frozen and lyophilized, while the other was left at $25^{\circ} \mathrm{C}$ in the dark for 6 hours, then frozen and lyophilized. These lyophilized samples, pure AlPc, 
and PVM/MA were then analyzed for their transmittance spectra in the infrared region of the electromagnetic spectrum with a Fourier transform infrared spectrophotometer (FTIR) (FT/IR 4100; Jasco Products Company, Oklahoma City, OK, USA) with a resolution of $4 \mathrm{~cm}^{-1}$, in the range of $500-4,000 \mathrm{~cm}^{-1}$.

\section{Detection of singlet oxygen}

Singlet oxygen was detected by a previously reported spectroscopic method. ${ }^{25,26}$ This method is based on the fact that the probe 1,3-diphenylisobenzofuran (DPBF) reacts irreversibly with singlet oxygen, causing a directly proportional decrease in the DPBF-specific optical density at $\lambda 414 \mathrm{~nm} \cdot{ }^{25,26}$ Briefly, $5 \mu \mathrm{L}$ of $5.5 \mathrm{mM}$ DPBF in ethanol were added to $600 \mu \mathrm{L}$ aliquots of the following samples: AlPc in ethanol; AlPc in PBS; AlPc-NPs in PBS; dissolved AlPc-NPs in PBS; and pure PVM/MA NPs in PBS. Then, each mixture was irradiated with a laser ( $\lambda 670 \mathrm{~nm}$; energy density of $0.5 \mathrm{~J} / \mathrm{cm}^{2}$ ). Absorption of the samples was read at $414 \mathrm{~nm}$ before and after irradiation. The difference between optical densities before and after irradiation was used as an index of singlet oxygen production. Samples without DPBF were used as blanks. The concentration of AlPc in all samples was $1 \mu \mathrm{M}$. The concentration of PVM/MA in AlPc-NPs and pure dispersed PVM/MA NPs was $0.6 \mathrm{mg} / \mathrm{mL}$.

\section{Cells and culture conditions}

Cancerous (4T1 [murine] and MCF-7 [human]) and noncancerous (NIH/3 T3 [murine] and MCF-10A [human]) cell lines were used in this work. NIH/3T3, 4T1, and MCF-7 cells were cultured in DMEM, and supplemented with $10 \%$ (v:v) fetal bovine serum and $1 \%(\mathrm{v}: \mathrm{v})$ antibiotic solution $(100 \mathrm{IU} / \mathrm{mL}$ penicillin and $100 \mathrm{mg} / \mathrm{mL}$ streptomycin). MCF-10A cells were cultured in DMEM/F12 (1/1, v:v) supplemented with $5 \%$ (v:v) equine serum, $20 \mathrm{ng} / \mathrm{mL}$ of epidermal growth factor, $10 \mu \mathrm{g} / \mathrm{mL}$ of bovine insulin, $0.5 \mu \mathrm{g} / \mathrm{mL}$ of hydrocortisone, $100 \mathrm{ng} / \mathrm{mL}$ of cholera toxin, and $1 \%(\mathrm{v}: \mathrm{v})$ antibiotic solution (100 IU/mL penicillin and $100 \mathrm{mg} / \mathrm{mL}$ streptomycin). All cells were maintained at $37^{\circ} \mathrm{C}$ in a $5 \% \mathrm{CO}_{2}$ and humidified atmosphere.

\section{AIPc-NP incorporation/ adsorption by cells}

This experiment was performed to check the time profile of AlPc-NP incorporation/adsorption by cell lines used in this work. Briefly, 4T1, MCF-7, NIH/3T3, and MCF-10A cells were cultured for 24 hours according to conditions described in the Cells and culture conditions section, at a density of
$1 \times 10^{3}$ cells/well in 96-well plates. Then, the culture medium was replaced by $200 \mu \mathrm{L}$ of AlPc-NPs dispersed in culture medium at a concentration of AlPc of $0.25 \mu \mathrm{M}$. Next, cells were incubated at $37^{\circ} \mathrm{C}, 5 \% \mathrm{CO}_{2}$, and $80 \%$ humidity for 1 minute, 5 minutes, 10 minutes, 15 minutes, 30 minutes, or 60 minutes, in the dark. Then, the culture medium was removed, the cells were washed twice with $200 \mu \mathrm{L}$ of PBS, and the AlPc was extracted with $200 \mu \mathrm{L}$ of dimethyl sulfoxide for 30 minutes. Next, fluorescence was read at ex $\lambda 350 \mathrm{~nm}$ and em $\lambda 680 \mathrm{~nm}$. This experiment was performed with two different pools of cells in quintuplicate, and the results were expressed as normalized fluorescence intensity.

\section{Intracellular distribution of AIPc-NPs}

The intracellular localization of AlPc-NPs was visualized by confocal microscopy. For this experiment, 4T1, MCF-7, $\mathrm{NIH} / 3 \mathrm{~T} 3$, and MCF-10A cells were cultured on coverslips placed in a 24-well plate for 24 hours, according to the conditions described in the Cells and culture conditions section, at a density of $2 \times 10^{4}$ cells/well. Next, cells were exposed to AlPc-NPs dispersed in culture medium at a concentration equivalent to $0.25 \mu \mathrm{MAlPc}$ for 15 minutes, at $37^{\circ} \mathrm{C}, 5 \% \mathrm{CO}_{2}$, and $80 \%$ humidity, then washed twice with PBS, fixed with paraformaldehyde $4 \%(\mathrm{w}: \mathrm{v})$ for 30 minutes, again washed twice with PBS, and mounted on glass slides. Next, cells were visualized in a confocal microscope (Leica TCS SP5, Leica Microsystems, Wetzlar, Germany) and AlPc fluorescence was detected at ex $\lambda 405 \mathrm{~nm}$ and em $\lambda 633 \mathrm{~nm}$.

\section{Cell treatment design}

4T1, MCF-7, NIH/3T3, and MCF-10A cells were cultured for 24 hours under the standard conditions described above. Next, cells were treated as follows: 1) irradiated with a laser $(\lambda 670 \mathrm{~nm})$ at energy densities of $0.0 \mathrm{~J} / \mathrm{cm}^{2}, 3.8 \mathrm{~J} / \mathrm{cm}^{2}$, $11.5 \mathrm{~J} / \mathrm{cm}^{2}, 22.9 \mathrm{~J} / \mathrm{cm}^{2}$, and $34.4 \mathrm{~J} / \mathrm{cm}^{2} ; 2$ ) exposed to blank PVM/MA NPs dispersed in PBS for 15 minutes in the dark at concentrations of $0.15 \mathrm{mg} / \mathrm{mL}, 0.3 \mathrm{mg} / \mathrm{mL}, 0.6 \mathrm{mg} / \mathrm{mL}$, $1.2 \mathrm{mg} / \mathrm{mL}, 2.4 \mathrm{mg} / \mathrm{mL}, 4.8 \mathrm{mg} / \mathrm{mL}$, and $7.2 \mathrm{mg} / \mathrm{mL}$ of PVM/MA; 3) exposed to AlPc-NPs dispersed in PBS for 15 minutes in the dark at concentrations of $0.25 \mu \mathrm{M}, 0.5 \mu \mathrm{M}$, $1.0 \mu \mathrm{M}, 2.0 \mu \mathrm{M}, 4.0 \mu \mathrm{M}, 8.0 \mu \mathrm{M}$, and $12.0 \mu \mathrm{M}$ of AlPc; and 4) exposed to AlPc-NPs dispersed in PBS for 15 minutes in the dark at concentrations of $0.25 \mu \mathrm{M}, 0.5 \mu \mathrm{M}, 1.0 \mu \mathrm{M}$, and $2.0 \mu \mathrm{M}$ of AlPc, washed twice with PBS, and then irradiated with a laser $(\lambda 670 \mathrm{~nm})$ at energy densities of $0.0 \mathrm{~J} / \mathrm{cm}^{2}$, $0.48 \mathrm{~J} / \mathrm{cm}^{2}, 1.38 \mathrm{~J} / \mathrm{cm}^{2}$, and $3.82 \mathrm{~J} / \mathrm{cm}^{2}$.

After the treatments, cells were cultured for 24 hours under standard conditions and their viability was assessed 
by the 3,(4,5-dimethylthiazol-2-yl)-2,5-diphenyltetrazolium bromide (MTT) assay, as described in Assessment of cell viability.

\section{Assessment of cell viability}

Cell viability was assessed by exposing cells to the yellow dye MTT assay, which is converted by the mitochondria of viable cells to an insoluble purple formazan. ${ }^{27}$ Briefly, after receiving their respective treatment, cells were washed twice with PBS and then incubated with $0.5 \mathrm{mg} / \mathrm{mL}$ of MTT in culture medium for 2.5 hours at $37^{\circ} \mathrm{C}, 5 \% \mathrm{CO}_{2}$, and $80 \%$ humidity. Next, the MTT solution was removed and formazan was extracted from the cells with $200 \mu \mathrm{L}$ of dimethyl sulfoxide (DMSO). The absorption was then measured at $\lambda 595 \mathrm{~nm}$ using a spectrophotometer (Spectramax ${ }^{\circledR}$ M2; Molecular Devices LLC). This experiment was performed in quintuplicate for each treatment, and the results were expressed as percentages relative to control.

\section{Detection of fragmented DNA}

This experiment is based on the fact that propidium iodide (PI) binds DNA, allowing cell DNA content to be measured by flow cytometry. Briefly, 4T1, MCF-7, NIH/3T3, and MCF-10A cells were cultured under standard culture conditions on 12-well microplates at a density of $3 \times 10^{4}$ cells/ well for 24 hours. Next, the culture medium was removed, cells were washed twice with PBS, and $400 \mu \mathrm{L}$ of AlPc-NPs dispersed in culture medium was added to each well, at the AlPc-NP lethal concentration $\mathrm{LC}_{50}$ specific to each cell line, as follows: $0.3 \mu \mathrm{M}$ to $4 \mathrm{~T} 1 ; 0.6 \mu \mathrm{M}$ to $\mathrm{NIH} / 3 \mathrm{~T} 3 ; 1.8 \mu \mathrm{M}$ to MCF-7; and $0.5 \mu \mathrm{M}$ to MCF-10A. $\mathrm{LC}_{50}$ was calculated based on the viability of the cells exposed to different concentrations of AlPc-NPs, and they were then irradiated with laser $(\lambda 670 \mathrm{~nm})$ at $0.48 \mathrm{~J} / \mathrm{cm}^{2}$. After 15 minutes of incubation with AlPc-NPs, the culture medium was removed, cells were washed twice with PBS, $400 \mu \mathrm{L}$ PBS was added to each well, and cells were then irradiated with a laser $(\lambda 670 \mathrm{~nm})$ at 0.48 or $1.38 \mathrm{~J} / \mathrm{cm}^{2}$. Next, PBS was replaced by a culture medium and cells were cultured under standard conditions for 24 hours. Then, the floating and adhered cells were harvested, centrifuged, and resuspended in $100 \mu \mathrm{L}$ of PBS. For DNA fragmentation analysis, $200 \mu \mathrm{L}$ of a PI-containing buffer $\left(0.1 \% \mathrm{w}: \mathrm{v}\right.$ sodium citrate, $0.1 \% \mathrm{w}: \mathrm{v}$ Triton $^{\mathrm{TM}} \mathrm{X}-100$ and $20 \mu \mathrm{g} / \mathrm{mL}$ PI; Life Technologies) was added, and the mixture was then incubated for 30 minutes in the dark at RT. Next, samples were evaluated using FACSscan ${ }^{\mathrm{TM}}$ flow cytometry (FACSCalibur ${ }^{\mathrm{TM}}$; BD Biosciences, San Jose, CA, USA) at FL2-H (fluorescence 2 height; $560-580 \mathrm{~nm}$ ) and analyzed by the CellQuest ${ }^{\mathrm{TM}}$ software (BD Biosciences). Ten thousand events were counted in triplicate per sample in the CyFlow ${ }^{\circledR}$ Space cytometer (Partec GmbH, Münster, Germany). Fragmented DNA was identified in sub-G1 (DNA content $<2 \mathrm{n}$ ) populations. This experiment was performed twice, and the results were expressed as the percentage of events presenting fragmented DNA in all counted events.

\section{Cell death analysis}

The frequency of cell death by apoptosis or necrosis was analyzed after AlPc-NP-based PDT in vitro by the acridine orange/ethidium bromide double staining method. ${ }^{28}$ Briefly, cells were cultured under standard culture conditions for 24 hours in 12-well plates at a density of $3 \times 10^{4}$ cells/well. Then, culture medium was removed, and the cells were washed twice with PBS and exposed to $400 \mu \mathrm{L}$ of AlPc-NPs in PBS at $\mathrm{LC}_{50}$, as described before, for 15 minutes. Cells were washed twice with PBS; $400 \mu \mathrm{L}$ of PBS was added to each well, and then cells were irradiated with a laser $(\lambda 670 \mathrm{~nm})$ at $0.48 \mathrm{~J} / \mathrm{cm}^{2}$ or $1.38 \mathrm{~J} / \mathrm{cm}^{2}$. Next, cells were washed twice with PBS and cultured under standard conditions for 24 hours. Floating and adhered cells were then harvested, centrifuged, resuspended in $100 \mu \mathrm{L}$ of PBS containing $50 \mu \mathrm{g} / \mathrm{mL}$ orange acridine and $50 \mu \mathrm{g} / \mathrm{mL}$ ethidium bromide, and left in the dark at RT for 5 minutes. Ten microliters of that suspension of cells were dispersed on a glass slide and analyzed in a fluorescence microscope. This experiment was performed twice, and 100 cells were analyzed per sample in triplicate, in three different regions of the slide. Results were expressed as the mean \pm SEM of the percentage of cells in apoptosis or necrosis.

\section{Statistical analysis}

Correlation between variables was analyzed with the Spearman test. Statistical differences between groups were assessed by one-way analysis of variance, followed by Tukey or Bonferroni's posttests $(\alpha=0.05)$ on GraphPad Prism 5.0 software (GraphPad Software, Inc., La Jolla, CA, USA).

\section{Results and discussion}

Hydrophobic phthalocyanine derivatives present excellent photophysical and photochemical characteristics, as well as rapid accumulation in cancerous cells. ${ }^{9}$ However, the issue of their aggregation in aqueous media has severely limited their application in anticancer PDT. In this context, waterdispersible nanocarriers have been proposed to circumvent this problem. ${ }^{5,15,29}$ In the present work, a third-generation system intended for anticancer PDT, composed of a hydrophobic 
phthalocyanine derivative associated to PVM/MA NPs, is described.

\section{PVM/MA concentration}

\section{affects colloid characteristics}

The PVM/MA NPs were produced by a solvent displacement method based on a previous work. ${ }^{24}$ This method enabled the HD of PVM/MA NPs to be tuned by simply controlling the initial concentration of the polymer, corroborating previous work. ${ }^{30}$ There was a significant positive correlation between the concentration of PVM/MA and the HD of NPs produced by solvent displacement $\left(r_{\text {Spearman }}=0.95 ; P<0.01 ;\right.$ Figure $\left.1 \mathrm{~A}\right)$. Narrow particle size distributions were obtained in the range of $20-40 \mathrm{mg} / \mathrm{mL}(2.5 \%-5.0 \% \mathrm{w}: \mathrm{w}$, in acetone) with PDI values below 0.1 , while poor quality colloids were obtained only for both the lowest and highest PVM/MA concentrations tested, as indicated by their higher values of PDI. In subsequent experiments, the concentration of PVM/MA was

A ○ PDI

- Hydrodynamic diameter $(\mathrm{nm})$
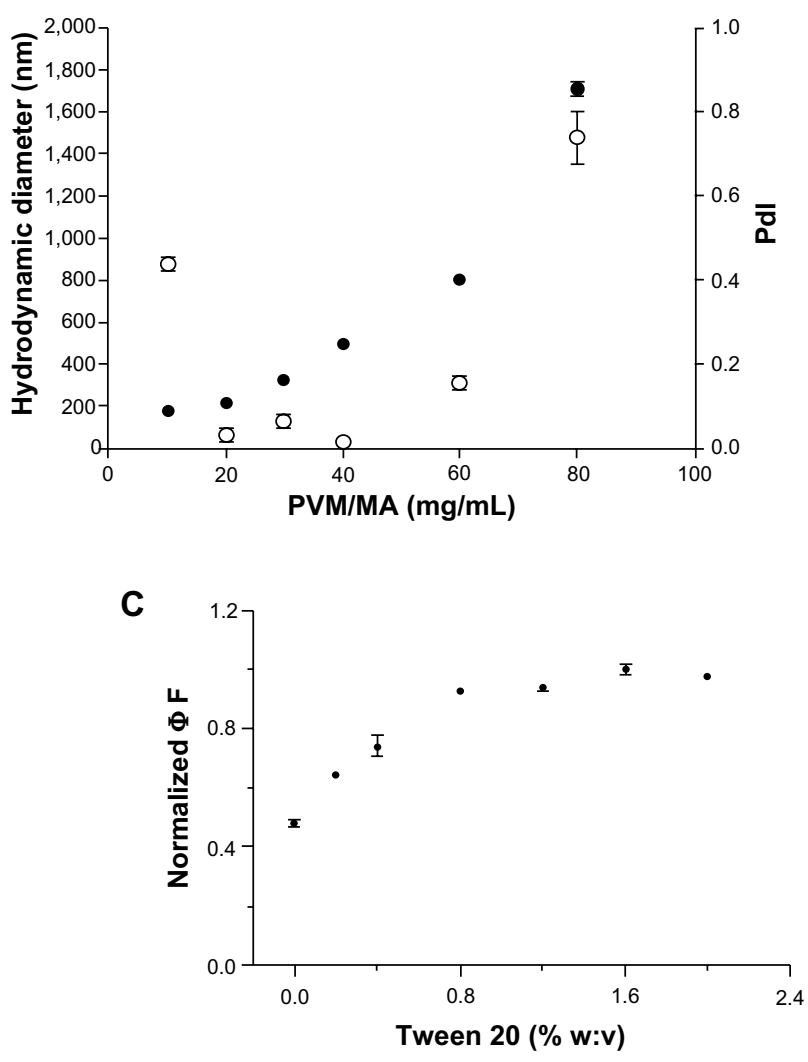

set to $20 \mathrm{mg} / \mathrm{mL}$ because it yielded NPs with an average HD of about $200 \mathrm{~nm}$, which is interesting for parenteral administration and drug delivery purposes. ${ }^{18}$

\section{$\Phi \mathrm{F}$ is affected by the concentrations of Tween 20 and AIPc}

AlPc was associated to the preformed NPs dispersed in the precipitation medium, which is aqueous and thus promotes the aggregation of AlPc. Therefore, in order to avoid AlPc aggregation, the surfactant Tween 20 was added to the precipitation medium. This surfactant markedly reduced the aggregation of AlPc associated to PVM/ MA NPs (AlPC-NPs). Consequently, a significant positive correlation was observed between the concentration of Tween 20 in the precipitation medium and the $\Phi F$ of AlPC-NPs $\left(r_{\text {Spearman }}=0.96 ; P<0.01\right.$; Figure 1C). In subsequent experiments, Tween 20 was added at $1.5 \%(w: v)$ to the precipitation medium.
B
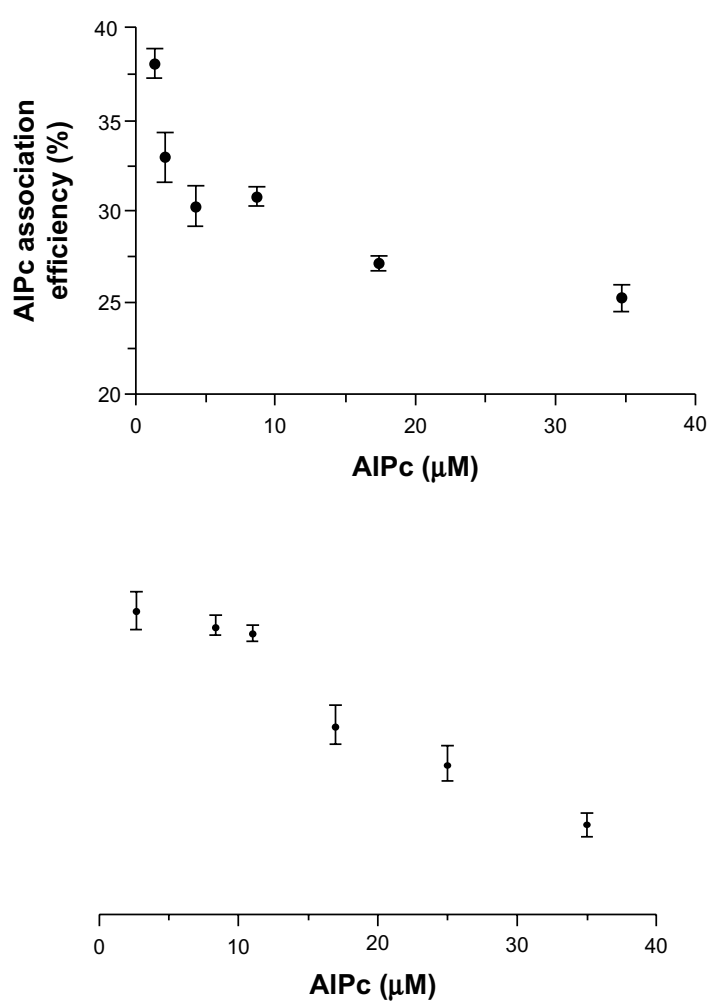

Figure I The effect of some process parameters on colloid and photophysical characteristics of nanoparticles.

Notes: (A) Hydrodynamic diameter and PDI of PVM/MA nanoparticles produced by solvent displacement in function of the initial PVM/MA concentration. (B) Efficiency of the AIPc association to PVM/MA nanoparticles in the function of the AIPc concentration in precipitation medium; (C) influence of Tween 20 and AlPc concentrations on the $\Phi \mathrm{F}$ (excitation $\lambda 350 \mathrm{~nm}$, emission $\lambda 690 \mathrm{~nm}$ ) of AlPc nanoparticles dispersed in phosphate buffered saline, $\mathrm{pH} 7.2$, at a concentration equivalent to I $\mu \mathrm{M}$ AlPc.

Abbreviations: PVM/MA, poly(methyl vinyl ether-co-maleic anhydride; AIPc, aluminum-phthalocyanine chloride; $\Phi F$, fluorescence quantum yield; PDI, polydisperity index. 
The results also showed that the concentration of AlPc affects the $\Phi F$ of the final formulation. Figure 1C shows a negative, significant correlation between the concentration of AlPc used in the precipitation medium and the $\Phi F$ of AlPc$\mathrm{NPs}\left(r_{\text {Spearman }}=-0.98 ; P<0.001\right)$. When prepared with $35 \mu \mathrm{M}$ of AlPc, for example, AlPc-NPs presented a value of $\Phi$ F that was about only $30 \%$ of that observed for the formulation prepared with $11 \mu \mathrm{M}$ AlPc. This is probably related to the effect of the mean distance between vicinal AlPc molecules on the intensity of quenching effects. ${ }^{11,31,32}$

\section{AIPc association efficiency}

As Figure 1B shows, there was a significant negative correlation between the efficiency of association of AlPc to PVM/MA NPs and the initial AlPc concentration used in the process $\left(r_{\text {Spearman }}=-0.83 ; P<0.05\right)$. In subsequent experiments, the initial AlPc concentration was set to $10 \mu \mathrm{M}$ in the precipitation medium.

\section{Colloid characterization}

PVM/MA NPs, either with AlPc (AlPc-NPs) or without AlPc (NPs), showed narrow particle size distribution, PDI below 0.1 , and negative zeta potential in aqueous medium at $\mathrm{pH} 7.2$ (Figure 2). The negative zeta potential reflects the presence of carboxylate groups on the surface of NPs. AlPc load in AlPc-NP was $0.9 \mu \mathrm{g} / \mathrm{mg}$, as determined in the lyophilized samples. The HD did not significantly change with the association of AlPc to NPs, and was close to 200 $\mathrm{nm}$ for both NP and AlPc-NP. None of these characteristics was significantly affected by a freeze/thaw cycle, and all remained stable for at least 60 days at $-20^{\circ} \mathrm{C}$. Moreover, AlPc-NPs are spherically shaped, as shown by scanning electron microscope images.

\section{Photophysical characterizations}

The photophysical characteristics of AlPc-NP were assessed and compared to those of free AlPc. In comparison to free AlPc in PBS, an aqueous medium, AlPc-NP presented improved photophysical and photochemical characteristics. Both the absorption and fluorescence of free AlPc are close to zero in PBS (Figure 3) - a medium that promotes aggregation of this molecule. ${ }^{13}$ On the other hand, when dissolved in ethanol, AlPc showed intense absorption with its typical strong Q band $(670 \mathrm{~nm})$ and intense fluorescence emission. When associated to PVM/MA NPs (AlPc-NPs) dispersed in PBS, AlPc presented intense absorption and fluorescence, with a hyperchromic effect in relation to free AlPc in PBS and a bathochromic shift of about $10 \mathrm{~nm}$ for both fluorescence emission and absorption peaks in comparison to free AlPc in ethanol. The peak observed at $720 \mathrm{~nm}$ is due to the turbidity of the NP suspensions (NP/PBS and AlPc-NP/PBS), and this fades away after the dissolution of NPs.

The dissolution of AlPc-NPs occurred within a few hours, as evidenced by the gradual decrease in the turbidity of the

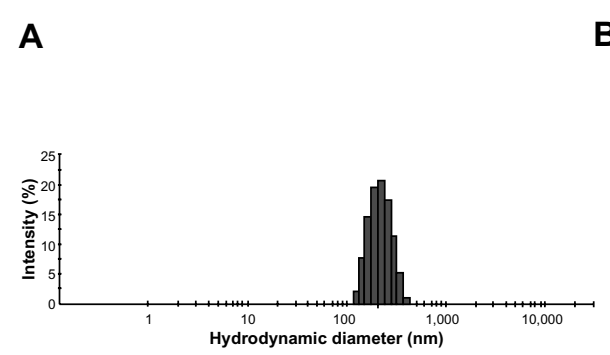

C

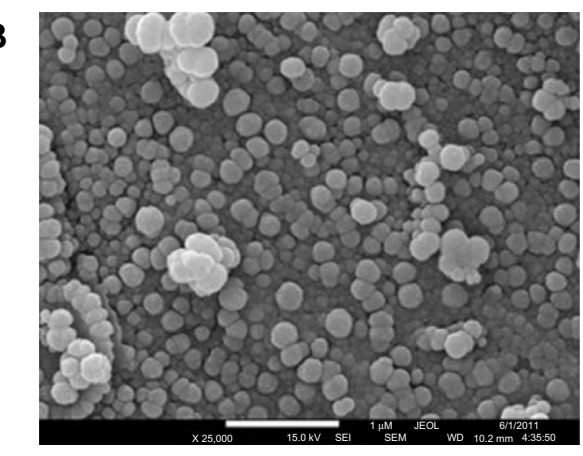

\begin{tabular}{lccc}
\hline & $\begin{array}{c}\text { Hydrodynamic diameter } \\
(\mathbf{n m})\end{array}$ & PDIs & $\begin{array}{c}\text { Zeta potential } \\
(\mathbf{m v})\end{array}$ \\
\hline AlPc-NPs (fresh) & $201.1 \pm 4.9$ & $0.043 \pm 0.009$ & $-19.7 \pm 0.54$ \\
NPs (fresh) & $207.5 \pm 1.2$ & $0.031 \pm 0.011$ & $-21.0 \pm 0.38$ \\
AlPc-NPs (frozen/thawed) & $206.2 \pm 4.6$ & $0.050 \pm 0.015$ & $-20.4 \pm 0.61$ \\
NPs (frozen/thawed) & $208.9 \pm 1.5$ & $0.042 \pm 0.013$ & $-20.6 \pm 0.47$ \\
\hline
\end{tabular}

Figure 2 Characteristics of PVM/MA NPs with AIPc-NPs or without AIPc-NPs.

Notes: (A) Histogram showing the distribution of the AlPc-NPs' hydrodynamic diameter values; (B) scanning electron microscopy image of AlPc-NPs; (C) colloidal characteristics of AIPc-NPs and NPs, fresh and after a single cycle of freezing/thawing. (B and $\mathbf{C}$ ) Nanoparticles were suspended in phosphate buffered saline, pH 7.2. Abbreviations: AIPc, aluminum-phthalocyanine chloride; NPs, nanoparticles; PVM/MA, poly(methyl vinyl ether-co-maleic anhydride); PDI, polydispersity index. 
Before particle dissolution
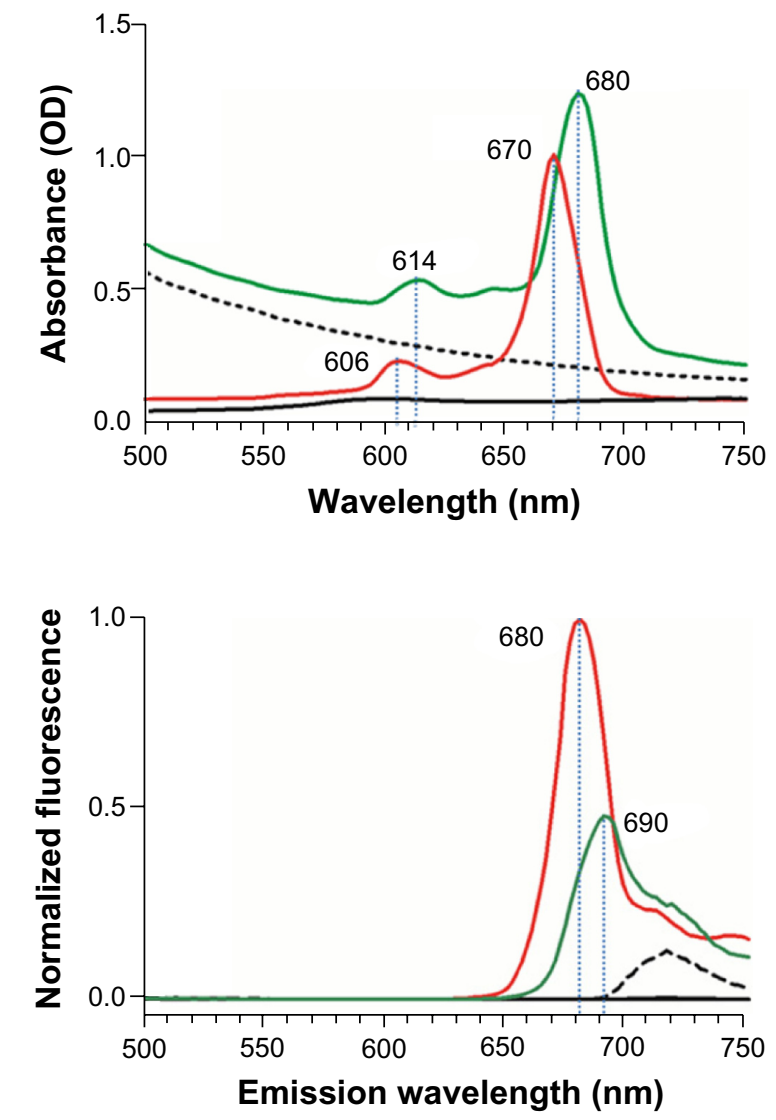

After particle dissolution

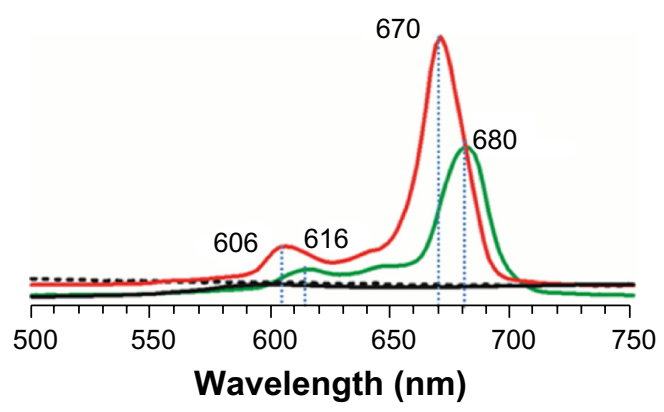

Figure 3 Absorbance and fluorescence (excitation at $\lambda 350 \mathrm{~nm}$ ) spectra of NPs and AlPc-NPs (I $\mu$ M AIPc) dispersed in PBS, before and after NP dissolution, and of I $\mu$ M free AIPc in PBS or ethanol.

Abbreviations: OD, optical density; AIPc, aluminum-phthalocyanine chloride; PBS, phosphate buffered saline; NP, nanoparticle.

dispersion (Figure 4). The decrease in turbidity begins at about 1 hour and stops at 5 hours. At 6 hours, it was not possible to observe any remaining NPs in the scanning electron microscope images (data not shown). Interestingly, even after the complete dissolution of the AlPc-NPs in PBS, its photodynamic activity was maintained, suggesting that AlPc remains associated to PVM/MA even after the dissolution of NPs. In other systems, such as those based on poly(lactic-coglycolic) acid, the photodynamic activity of hydrophobic PS molecules in aqueous media may be significantly reduced after the disintegration of NPs. ${ }^{32,33}$ A strong Coulomb interaction between the negative, carboxylate groups of PVM/MA and the positive, metallic center of AlPc may be responsible for keeping AlPc associated to the polymer strands even after the dissolution of NPs.

\section{FTIR spectra}

PVM/MA anhydride groups readily react with water, producing carboxyl groups, as confirmed by the FTIR spectrum of AlPc-NPs exposed to water for 6 hours. It clearly shows an intense reduction in the intensity of the anhydride bands, at $1,770 \mathrm{~cm}^{-1}$ and $1,842 \mathrm{~cm}^{-1},{ }^{34}$ in comparison to the spectra of both fresh AlPc-NPs and pure PVM/MA (Figure 5). Moreover, two bands typical of carboxyl groups, at $1,362 \mathrm{~cm}^{-1}$ and $1,733 \mathrm{~cm}^{-1},{ }^{34}$ appeared for AlPc-NPs after 6 hours of exposure to water. Fresh AlPc-NPs also showed bands of carboxyl groups and a reduction in the intensity of anhydride bands, as a consequence of the exposure of PVM/MA to the water added during the process of NP preparation.

It is possible to control the time of PVM/MA dissolution in aqueous media through simple steps of NP surface 


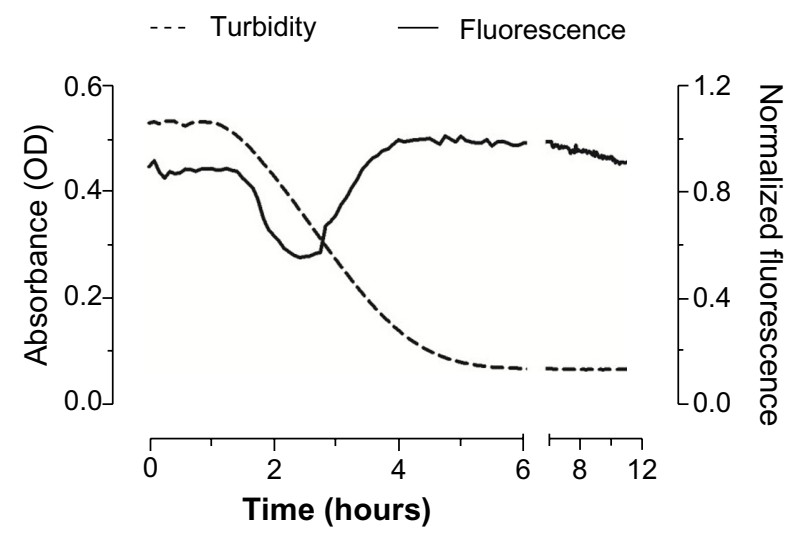

Figure 4 Variation of turbidity (absorbance at $\lambda 510 \mathrm{~nm}$ ) and fluorescence (excitation $\lambda 350 \mathrm{~nm}$, emmission $\lambda 670 \mathrm{~nm}$ ) with time for AlPc-NPs (I $\mu$ M AlPc) dispersed in PBS at $25^{\circ} \mathrm{C}$.

Abbreviations: OD, optical density; AIPc, aluminum-phthalocyanine chloride; NPs, nanoparticles; PBS, phosphate buffered saline.

modification, such as the crosslinking of polymer strands with a diamine ${ }^{23}$ or associating them with polymers by hydrogen bonds. This kind of modification can give the NPs some interesting properties for drug delivery and controlled release purposes.

Because of the anhydride groups, PVM/MA NPs also allow several targeting molecules to be easily converted to their surface. ${ }^{20,35}$ Moreover, carboxyl groups generated by the hydrolysis of anhydride groups form hydrogen bonds with other molecules exposed on the cell membrane and with other possible biological targets. ${ }^{23}$ This phenomenon can also be explored to increase the incorporation of PS molecules by target cells.

\section{AIPc-NP produces oxidant species in aqueous medium under light irradiation}

As Figure 6 shows, under irradiation with a laser $(\lambda 670 \mathrm{~nm}$; $0.5 \mathrm{~J} / \mathrm{cm}^{2}$ energy density), the level of oxidant species generated by AlPc-NPs in PBS was equivalent to more than $50 \%$ of that observed with free AlPc in ethanol; on the other hand, free AlPc in PBS reached less than 5\%. This result matches the increase in $\Phi F$ previously discussed and shows that the association of AlPc to PVM/MA NPs enhances the photochemical performance of this PS in aqueous media. After its dissolution, AlPc-NPs generated about 10\% more oxidant species in comparison to the fresh formulation.

\section{AlPc-NP is incorporated by cells in vitro}

Figure 7A shows that AlPc-NP was incorporated by both cancerous and noncancerous cells. It was observed that murine cancerous cells, $4 \mathrm{~T} 1$, incorporated $16.4 \%$ and $30.7 \%$ more

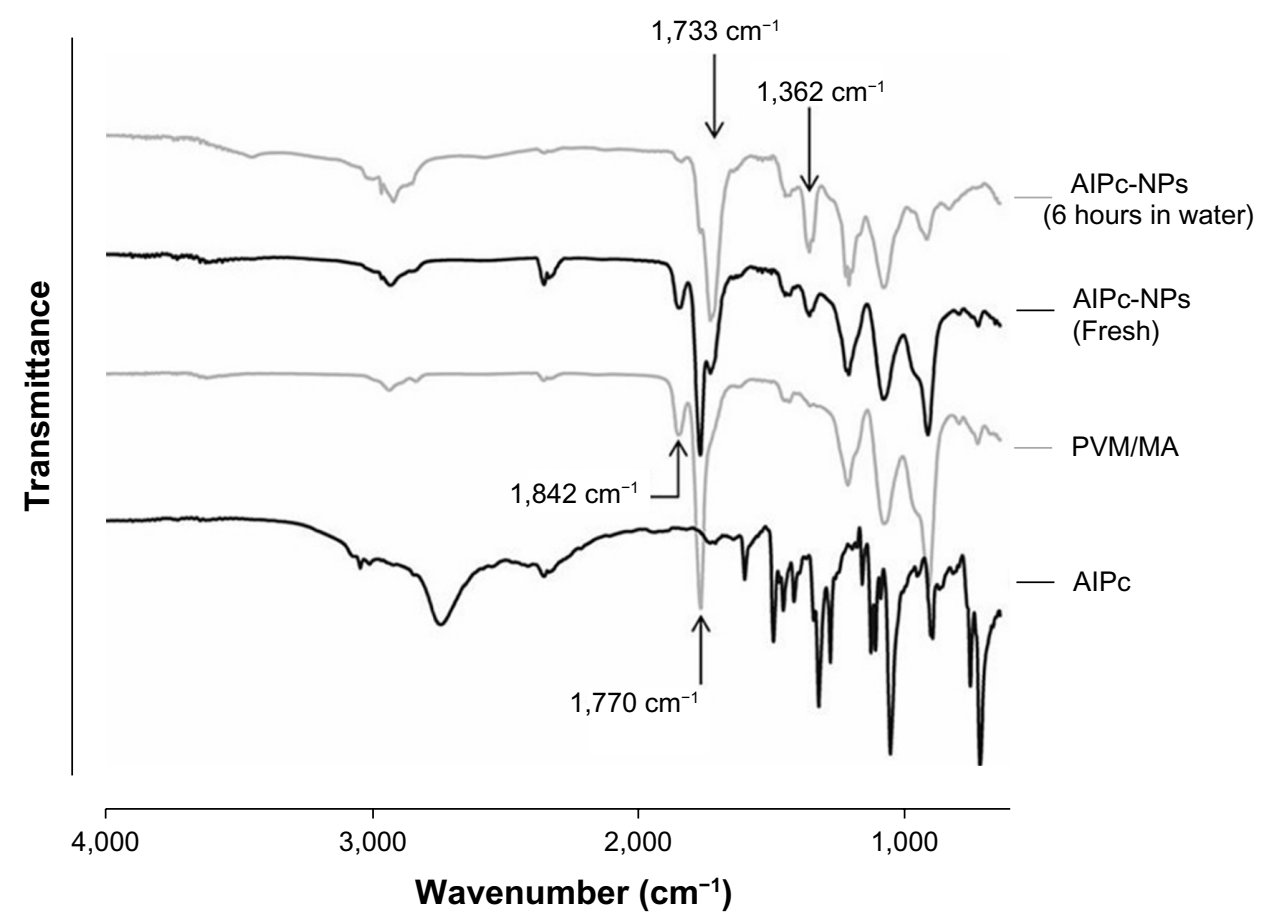

Figure 5 FTIR spectra of AIPc, PVM/MA, fresh AIPc-NPs, and AIPc-NPs exposed to water for 6 hours.

Notes: The appearance of carboxyl bands, at $1,362 \mathrm{~cm}^{-1}$ and I,733 $\mathrm{cm}^{-1}$, and the decrease in the intensity of anhydride bands, at I,770 $\mathrm{cm}^{-1}$ and I,842 $\mathrm{cm}^{-1}$, shows that the anhydride groups of PVM/MA are hydrolyzed when AIPc-NPs are exposed to water.

Abbreviations: AIPc, aluminum-phthalocyanine chloride; NPs, nanoparticles; PVM/MA, poly(methyl vinyl ether-co-maleic anhydride); FTIR, Fourier transform infrared spectrophotometer. 


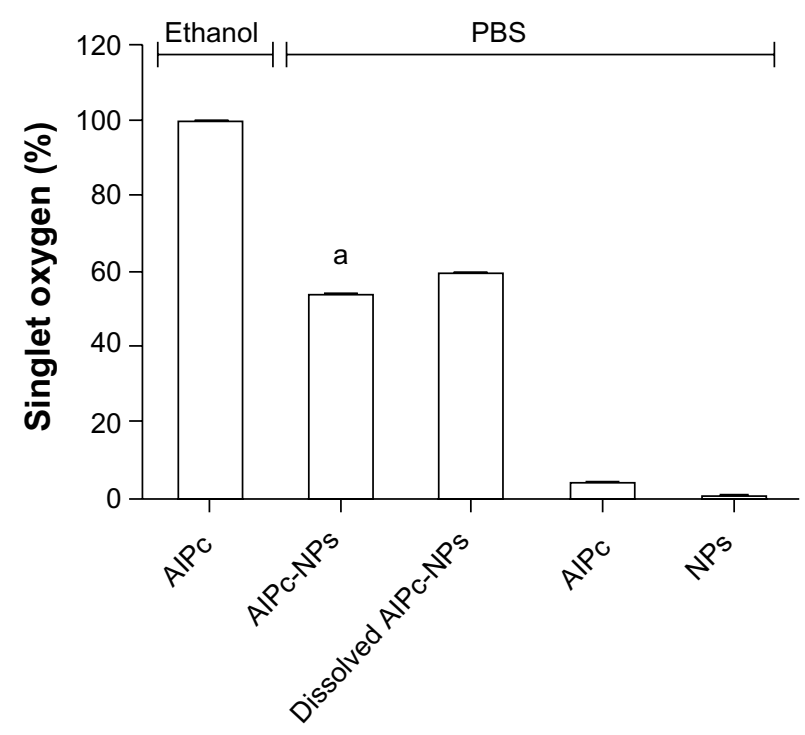

Figure 6 Generation of singlet oxygen by I $\mu$ M free AIPc in ethanol or PBS, and by pure PVM/MA NPs, fresh AIPc-NPs (I $\mu$ M AIPc), and dissolved AIPc-NPs (I $\mu \mathrm{M}$ $A I P c)$ in PBS under irradiation with a laser $\left(\lambda 670 \mathrm{~nm}\right.$, energy density of $\left.0.5 \mathrm{~J} / \mathrm{cm}^{2}\right)$. Note: ${ }^{a} P<0.05$ versus all the other groups.

Abbreviations: PBS, phosphate buffered saline; AIPc, aluminum-phthalocyanine chloride; NPs, nanoparticles; PVM/MA, poly(methyl vinyl ether-co-maleic anhydride).

AlPc-NPs than did murine noncancerous cells (NIH/3T3) at 30 minutes and 60 minutes of incubation, respectively. Cancerous cells of human origin (MCF-7) incorporated $18.8 \%$ and $73.9 \%$ more AlPc-NPs than did the noncancerous cells (MCF-10A) at 30 minutes and 60 minutes, respectively. The higher incorporation seen in cancerous cells may be due to the higher endocytic activity of these cells. ${ }^{17}$ Figure $7 \mathrm{~B}$ shows the intracellular distribution of AlPc-NPs after 15 minutes of exposure to AlPc-NP in cells from all lines. Fluorescence imaging by confocal microscopy clearly shows that AlPc-NP is concentrated in the cytosol of the cells.

\section{Photodynamic activity against cells in vitro}

The cytotoxic potential of laser, PVM/MA NPs, and AlPc-NP alone was evaluated. As Figure 8A and B show, laser and PVM/MA NPs, at any of the energy densities and concentrations tested, respectively, were not toxic to the studied cells. These results are in accordance with basic features of PDT, which assume that both the light source and drug carrier are innocuous when used separately. ${ }^{36}$ In addition, the absence of significant cell death after exposure to PVM/MA NPs shows that this material is biocompatible.

In Figure $8 \mathrm{C}$, a significant reduction in the viability of murine 4T1 and NIH/3T3 cells was noted when they were exposed in the dark to AlPc-NPs, starting at $4.0 \mu \mathrm{M}$ and $8.0 \mu \mathrm{M}$ of $\mathrm{AlPc}$, respectively. On the other hand, the same treatment was not cytotoxic to the human cell lines at any of the tested AlPc-NP concentrations, as shown in Figure $8 \mathrm{D}$. These results determined the highest nontoxic AlPc concentration $(2.0 \mu \mathrm{M})$ for the subsequent PDT experiments.

Even for cell lineages from the same species, different susceptibility to toxic compounds may be found. For different cancer cell lineages, the susceptibility to some substances may vary even more significantly than for normal cells, as differences in metabolism are easily observed in this kind of cell. ${ }^{37}$ Therefore, the species factor may not be responsible for the difference observed in our experiments.

After testing the cytotoxicity of isolated components of the system, and ensuring the internalization of AlPc by cells (Figure 7), PDT was performed in vitro with AlPc-NPs
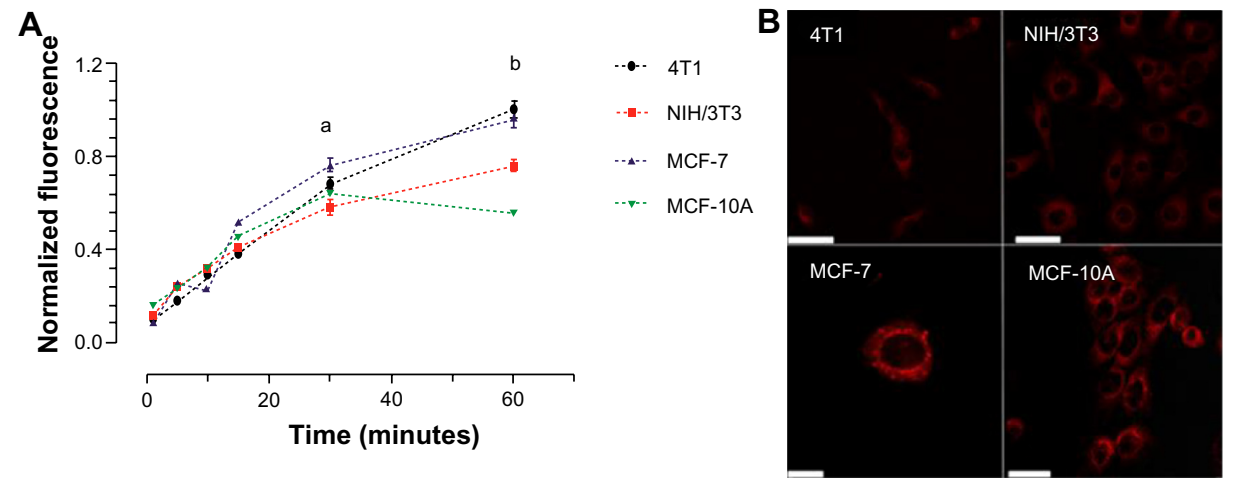

Figure 7 In vitro incorporation of AIPc-NPs by cancerous (4TI [murine] and MCF-7 [human]) and noncancerous (NIH/3T3 [murine] and MCF-I0A [human]) cells.

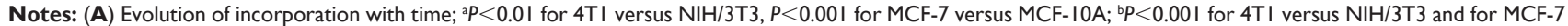
versus MCF-IOA. (B) Confocal images of cells exposed to AIPc associated to PVM/MA NPs (AIPc-NPs; concentration equivalent to $0.25 \mu$ M AIPc) for I5 minutes; AIPc appears in red; the scale bar (white rod) length is equal to $50 \mu \mathrm{m}$ for 4TI, NIH/3T3, and MCF-I0, and I0 $\mu \mathrm{m}$ for MCF-7.

Abbreviations: AIPc, aluminum-phthalocyanine chloride; NPs, nanoparticles; PVM/MA, poly(methyl vinyl ether-co-maleic anhydride). 
$4 \mathrm{~T} 1$

$\mathrm{NIH} / 3 \mathrm{T3}$
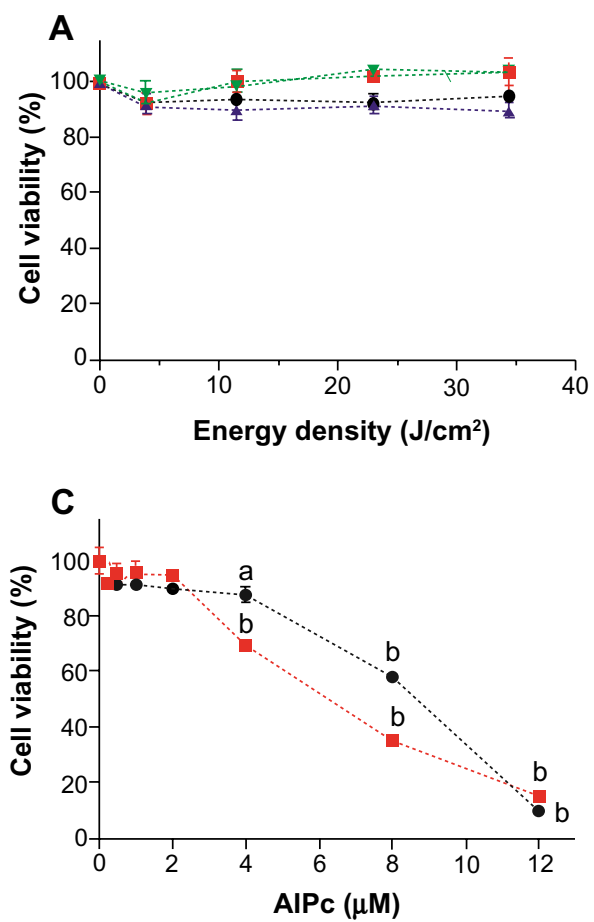
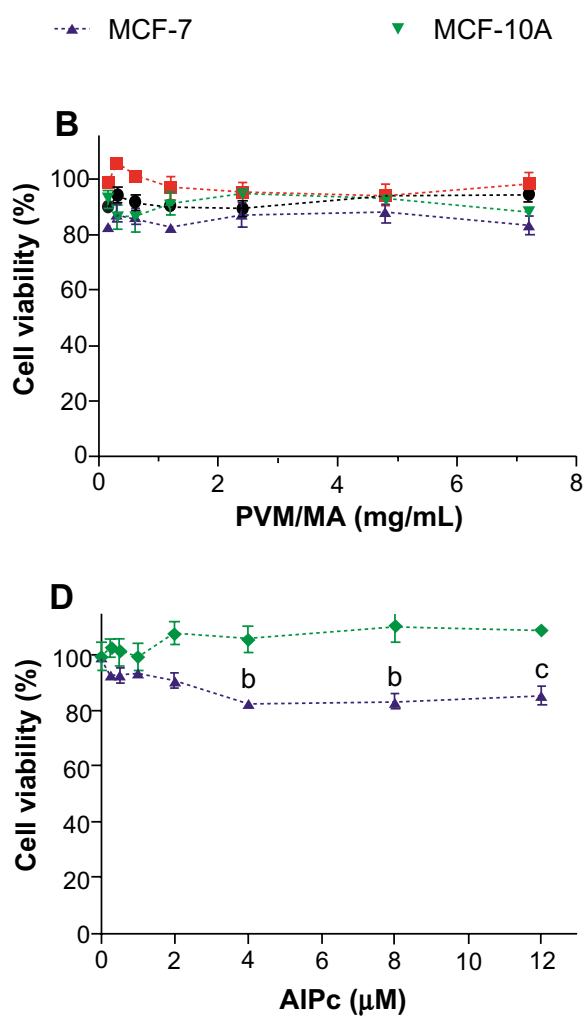

Figure 8 Viability of cancerous (4TI [murine] and MCF-7 [human]) and noncancerous (NIH/3T3 [murine] and MCF-IOA [human]) cells after exposure to laser alone, PVM/ MA NPs, and AIPc associated to PVM/MA NPs.

Notes: (A) Laser $(670 \mathrm{~nm})$ alone; (B) PVM/MA NPs in the dark; and (C and D) AlPc associated to PVM/MA NPs (AIPc-NPs) in the dark. (A and B) There were no statistically significant differences between the viabilities of treated and nontreated cells. a $P<0.05$ versus $0 \mu \mathrm{M}$; ${ }^{b} P<0.00 \mathrm{I}$ versus $0 \mu \mathrm{M}$; ${ }^{c} P<0.0 \mathrm{I}$ versus $0 \mu \mathrm{M}$.

Abbreviations: PVM/MA, poly(methyl vinyl ether-co-maleic anhydride); AlPc, aluminum-phthalocyanine chloride; NPs, nanoparticles.

at different concentrations. Figure 9 shows that PDT with AlPc-NPs was able to induce significant reductions in the viability of cells from all lines. For murine cells (4T1 and $\mathrm{NIH} / 3 \mathrm{~T} 3$ ) and human cancerous cells (MCF-7) at low laser energy densities, cytotoxicity was clearly dependent on the concentration of AlPc-NP. At the highest laser energy density, $3.82 \mathrm{~J} / \mathrm{cm}^{2}$, the maximum effect was reached even at $0.25 \mu \mathrm{M}$ of AlPc-NP for all cells.

The observed cell death after AlPc-NP-mediated PDT (Figure 9), along with the finding that AlPc-NP is incorporated by both normal and cancerous cells (Figure 7), shows that AlPc-NP is delivered to cultured cells in a nonspecific manner. That was expected, since the specific delivery of drugs to the tumor with nanobased systems is mainly dependent on the altered physiological characteristics of cancerous tissues in vivo. . $^{38,39}$

Malignant neoplastic tissues have abnormal and aberrant blood vessels that are much more permeable to NPs when compared to normal noncancerous blood vessels. ${ }^{39}$ This phenomenon is classically referred to as the enhanced permeability and retention effect, and is one of the most important theories explaining the enhanced drug delivery to tumor tissues related to nanobased drug carriers. ${ }^{40,41}$ Therefore, the differences in the specificity of drug delivery are better observed in in vivo experimental methods.

\section{Cell death mechanism and DNA fragmentation}

Figure 10A shows that DNA fragmentation was more intense in cells treated with PDT at the lowest laser energy density tested $\left(0.48 \mathrm{~J} / \mathrm{cm}^{2}\right)$. This profile was observed for all the cell lines tested. On the other hand, DNA fragmentation in the cells receiving PDT at the highest energy density applied, $1.38 \mathrm{~J} / \mathrm{cm}^{2}$, was statistically equal to the control.

The results show a bell-shaped distribution of DNA damage in the function of energy density in all cell types. Interestingly, the predominant mechanism of cell death induced by AlPc-NP-mediated PDT was affected by the laser energy density applied. In Figure 10B, it is possible to note that in cells treated with PDT at the lowest laser energy density, apoptosis was predominant. On the other hand, at 

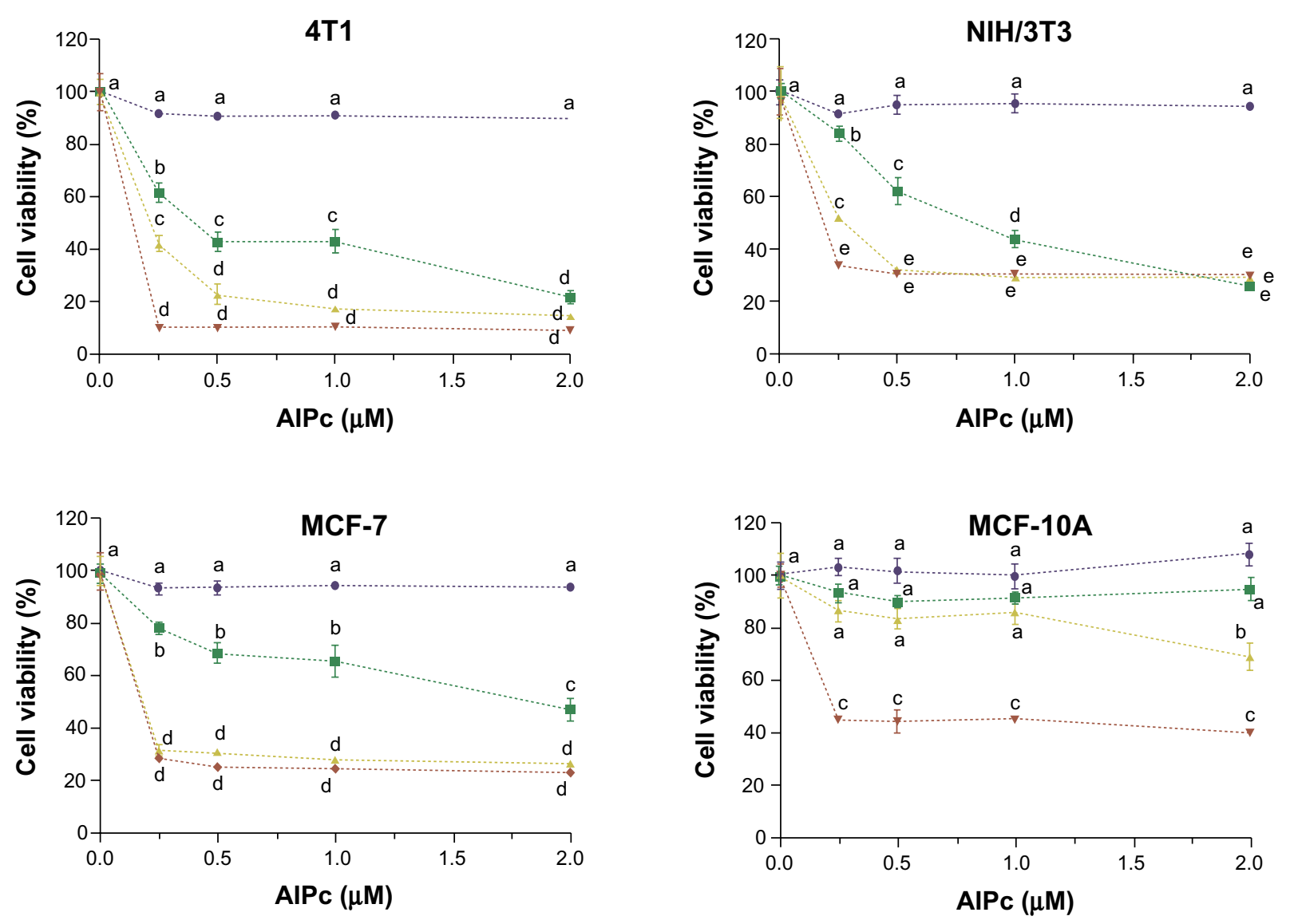

Legend

Energy density applied
- $0.00 \mathrm{~J} / \mathrm{cm}^{2}$
..- $\quad 0.48 \mathrm{~J} / \mathrm{cm}^{2}$
$1.38 \mathrm{~J} / \mathrm{cm}^{2}$
$3.82 \mathrm{~J} / \mathrm{cm}^{2}$

Figure 9 Viability of cancerous (4TI [murine] and MCF-7 [human]) and noncancerous (NIH/3T3 [murine] and MCF-IOA [human]) cells after exposure to AIPc associated to poly(methyl vinyl ether-co-maleic anhydride) nanoparticles, at different concentrations of AIPc, for 15 minutes followed by the application of light (laser, 670 nm) at different energy densities in vitro.

Note: Pairs of means in the same graph identified with different letters are statistically different $(P<0.05)$.

Abbreviation: AIPc, aluminum-phthalocyanine chloride.

higher energy density, necrosis was the predominant mechanism of cell death, and the frequency of cell death was also increased in the highest energy groups.

These results indicated that low-energy PDT leads to the activation of the effector mechanisms related to apoptosis in a typical oxidative stress-induced apoptosis pathway. ${ }^{42,43}$ In contrast, cells treated with high-energy PDT presented a predominant pattern of necrotic cell death. These observations are in accordance with other reports, which identified a significantly increased intracellular oxidative stress when high-light energies were applied in the PDT protocols in comparison with low-light energy protocols. ${ }^{44,45}$ When oxidative stress is too intense, as observed in the high-energy groups, the cellular machinery that initiates apoptosis is also affected, and cell death occurs via necrosis. ${ }^{45,46}$
Thus, at lower energy doses, limited damage is caused to cell structures. This damage is not enough to promote cell necrosis, but it is able to activate the cellular machinery responsible for the initiation of apoptosis. On the other hand, the more intense severe damage caused by higher energy doses is capable of significantly destroying important cell structures - such as the cell membrane, for example-leading to death by necrosis.

Interestingly, based on the fact that cell death by necrosis induces a robust inflammatory response and potentiates an antitumoral immune response, ${ }^{47}$ it is possible to suggest that the high-energy PDT can stimulate immune activation against the remaining tumor cells. Actually, this hypothesis has already been suggested and described as an advantage of PDT over traditional antitumor therapies, 

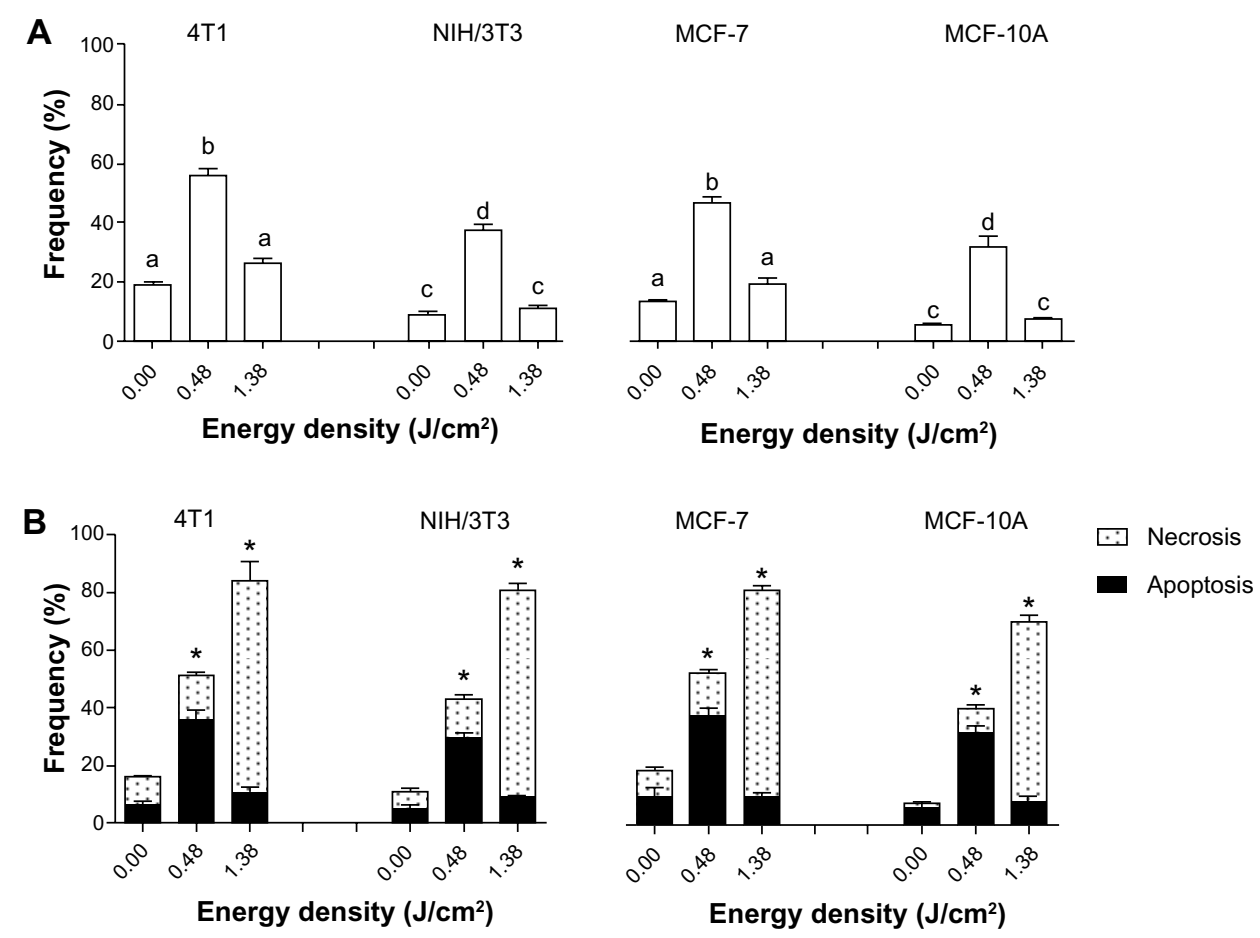

Figure 10 DNA fragmentation and cell death assessed after exposure of cells to LC at I0\% (LCI0) of AIPc-NPs for I5 minutes followed by the application of light (laser, $\lambda 670 \mathrm{~nm}$ ) at different energy densities in vitro.

Notes: (A) DNA fragmentation and (B) cell death. The values of $\mathrm{LC}_{50}$ for $4 \mathrm{TI}$, NIH/3T3, MCF-7, and MCF-I0A were $0.3 \mathrm{I} \mu \mathrm{M}$ AIPc, $0.63 \mu \mathrm{M}$ AIPc, $0.46 \mu \mathrm{M}$ AIPc, and I.80 $\mu \mathrm{M}$ AlPc, respectively. (A) The difference between pairs of means in the same graph identified with different letters are statistically significant $(P<0.05)$. (B) $* G r o u p s$ presenting with a statistically significant difference between the means for apoptosis and necrosis; no statistically significant differences were observed between the results of different cell lineages of the same origin.

Abbreviations: NPs, nanoparticles; LC, lethal concentrations; AIPc, aluminum-phthalocyanine chloride.

such as some chemotherapy protocols that are generally immunosuppressive. ${ }^{48-50}$

\section{Conclusion}

In conclusion, the system composed by AlPc associated to PVM/MA NPs presents photodynamic activity in aqueous media, and may be used for anticancer PDT. This new thirdgeneration PS should be further studied, especially for its drug delivery ability in in vivo models. Moreover, PVM/MA NPs may also be tested as a carrier for other PSs.

\section{Acknowledgments}

Financial support from the Brazilian agencies: National Counsel of Technological and Scientific Development (CNPq, Brasília, Distrito Federal, Brazil), Funding Authority for Studies and Projects (FINEP, Rio de Janeiro, Rio de Janeiro, Brazil), Agency for the Support and Evaluation of Graduate Education (CAPES, Brasília, Distrito Federal, Brazil), and Research Funding Foundation of Distrito Federal (FAP/DF, Brasília, Distrito Federal, Brazil) is gratefully acknowledged.

\section{Disclosure}

The authors report no conflicts of interest in this work.

\section{References}

1. Yano S, Hirohara S, Obata M, et al. Current states and future views in photodynamic therapy. Journal of Photochemistry and Photobiology C: Photochemistry Reviews. 2011;12(1):46-67.

2. Moore CM, Pendse D, Emberton M. Photodynamic therapy for prostate cancer - a review of current status and future promise. Nat Clin Pract Urol. 2009;6(1):18-30.

3. Dolmans DE, Fukumura D, Jain RK. Photodynamic therapy for cancer. Nat Rev Cancer. 2003;3(5):380-387.

4. MacDonald IJ, Dougherty TJ. Basic principles of photodynamic therapy. J Porphyr Phthalocyanines. 2001;5(2):105-129.

5. Figueiró Longo JP, Muehlmann LA, Vieira Velloso N, et al. Effects of photodynamic therapy mediated by liposomal aluminum-phthalocyanine chloride on chemically induced tongue tumors. Chemotherapy. 2012;1:2

6. Buytaert E, Dewaele M, Agostinis P. Molecular effectors of multiple cell death pathways initiated by photodynamic therapy. Biochim Biophys Acta. 2007;1776(1):86-107.

7. O'Connor AE, Gallagher WM, Byrne AT. Porphyrin and nonporphyrin photosensitizers in oncology: preclinical and clinical advances in photodynamic therapy. Photochem Photobiol. 2009;85(5): 1053-1074.

8. Detty MR, Gibson SL, Wagner SJ. Current clinical and preclinical photosensitizers for use in photodynamic therapy. J Med Chem. 2004;47(16):3897-3915. 
9. Chan WS, Marshall JF, Svensen R, Bedwell J, Hart IR. Effect of sulfonation on the cell and tissue distribution of the photosensitizer aluminum phthalocyanine. Cancer Res. 1990;50(15):4533-4538.

10. Kobayashi M, Kigawa Y, Satoh K, Sawada K. Solvent effect on the aggregation of amphiphilic phthalocyanines substituted by polyethyleneoxide. J Porphyr Phthalocyanines. 2012;16(2):183-191.

11. Lovell JF, Liu TW, Chen J, Zheng G. Activatable photosensitizers for imaging and therapy. Chem Rev. 2010;110(5):2839-2857.

12. Lim CK, Heo J, Shin S, et al. Nanophotosensitizers toward advanced photodynamic therapy of cancer. Cancer Lett. 2013;334(2):176-187.

13. Dhami S, Phillips D. Comparison of the photophysics of an aggregating and non-aggregating aluminum phthalocyanine system incorporated into unilamellar vesicles. J Photochem Photobiol A Chem. 1996;100(1-3): 77-84.

14. Nunes SM, Squilla FS, Tedesco AC. Photophysical studies of zinc phthalocyanine and chloroaluminum phthalocyanine incorporated into liposomes in the presence of additives. Braz J Med Biol Res. 2004;37(2):273-284.

15. Ricci-Júnior E, Marchetti JM. Preparation, characterization, photocytotoxicity assay of PLGA nanoparticles containing zinc (II) phthalocyanine for photodynamic therapy use. J Microencapsul. 2006;23(5):523-538.

16. Rossetti FC, Lopes LB, Carollo AR, Thomazini JA, Tedesco AC, Bentley MV. A delivery system to avoid self-aggregation and to improve in vitro and in vivo skin delivery of a phthalocyanine derivative used in the photodynamic therapy. $J$ Control Release. 2011;155(3):400-408.

17. Sharman WM, van Lier JE, Allen CM. Targeted photodynamic therapy via receptor mediated delivery systems. Adv Drug Deliv Rev. 2004;56(1):53-76.

18. Torchilin V. Tumor delivery of macromolecular drugs based on the EPR effect. Adv Drug Deliv Rev. 2011;63(3):131-135.

19. Josefsen LB, Boyle RW. Photodynamic therapy: novel third-generation photosensitizers one step closer? Br J Pharmacol. 2008;154(1):1-3.

20. Arbós P, Wirth M, Arangoa MA, Gabor F, Irache JM. Gantrez AN as a new polymer for the preparation of ligand-nanoparticle conjugates. J Control Release. 2002;83(3):321-330.

21. Arbós P, Campanero MA, Arangoa MA, Renedo MJ, Irache JM. Influence of the surface characteristics of PVM/MA nanoparticles on their bioadhesive properties. J Control Release. 2003;89(1):19-30.

22. Salman HH, Gamazo C, de Smidt PC, Russell-Jones G, Irache JM. Evaluation of bioadhesive capacity and immunoadjuvant properties of vitamin B(12)-Gantrez nanoparticles. Pharm Res. 2008;25(12): 2859-2868.

23. Irache JM, Huici M, Konecny M, Espuelas S, Campanero MA, Arbos P. Bioadhesive properties of Gantrez nanoparticles. Molecules. 2005;10(1):126-145.

24. Gómez S, Gamazo C, San Roman B, Vauthier C, Ferrer M, Irachel JM. Development of a novel vaccine delivery system based on Gantrez nanoparticles. J Nanosci Nanotechnol. 2006;6(9-10): 3283-3289.

25. He X, Wu X, Wang K, Shi B, Hai L. Methylene blue-encapsulated phosphonate-terminated silica nanoparticles for simultaneous in vivo imaging and photodynamic therapy. Biomaterials. 2009;30(29): 5601-5609.

26. Spiller W, Kliesch H, Wöhrle D, Hackbarth S, Röder B, Schnurpfeil G. Singlet oxygen quantum yields of different photosensitizers in polar solvents and micellar solutions. J Pept Res. 1998;2(2):145-158.

27. Mosmann T. Rapid colorimetric assay for cellular growth and survival: application to proliferation and cytotoxicity assays. J Immunol Methods. 1983;65(1-2):55-63.

28. Takahashi A, Matsumoto H, Yuki K, et al. High-LET radiation enhanced apoptosis but not necrosis regardless of p53 status. Int J Radiat Oncol Biol Phys. 2004;60(2):591-597.
29. da Volta Soares M, Oliveira MR, dos Santos EP, et al. Nanostructured delivery system for zinc phthalocyanine: preparation, characterization, and phototoxicity study against human lung adenocarcinoma A549 cells. Int J Nanomedicine. 2011;6:227-238.

30. Bally F, Garg DK, Serra CA, et al. Improved size-tunable preparation of polymeric nanoparticles by microfluidic nanoprecipitation. Polymer. 2012;53(22):5045-5051.

31. Master AM, Rodriguez ME, Kenney ME, Oleinick NL, Gupta AS. Delivery of the photosensitizer Pc 4 in PEG-PCL micelles for in vitro PDT studies. J Pharm Sci. 2010;99(5):2386-2398.

32. Vargas A, Eid M, Fanchaouy M, Gurny R, Delie F. In vivo photodynamic activity of photosensitizer-loaded nanoparticles: formulation properties, administration parameters and biological issues involved in PDT outcome. Eur J Pharm Biopharm. 2008;69(1):43-53.

33. Paszko E, Ehrhardt C, Senge MO, Kelleher DP, Reynolds JV. Nanodrug applications in photodynamic therapy. Photodiagnosis Photodyn Ther. 2011;8(1):14-29.

34. Li Y, Lee PI. A new bioerodible system for sustained local drug delivery based on hydrolytically activated in situ macromolecular association. Int J Pharm. 2010;383(1-2):45-52.

35. Salman HH, Gamazo C, Campanero MA, Irache JM. Salmonella-like bioadhesive nanoparticles. J Control Release. 2005;106(1-2):1-13.

36. Castano AP, Demidova TN, Hamblin MR. Mechanisms in photodynamic therapy: part one - photosensitizers, photochemistry and cellular localization. Photodiagnosis Photodyn Ther. 2004;1(4):279-293.

37. Lotan R. Different susceptibilities of human melanoma and breast carcinoma cell lines to retinoic acid-induced growth inhibition. Cancer Res. 1979;39(3):1014-1019.

38. Muehlmann LA, Joanitti GA, Silva JR, Longo JP, Azevedo RB. Liposomal photosensitizers: potential platforms for anticancer photodynamic therapy. Braz J Med Biol Res. 2011;44(8):729-737.

39. Nichols JW, Bae YH. Odyssey of a cancer nanoparticle: from injection site to site of action. Nano Today. 2012;7(6):606-618.

40. Yokoyama M. Drug targeting with nano-sized carrier systems. J Artif Organs. 2005;8(2):77-84

41. Maeda H, Wu J, Sawa T, Matsumura Y, Hori K. Tumor vascular permeability and the EPR effect in macromolecular therapeutics: a review. J Control Release. 2000;65(1-2):271-284.

42. Trinei M, Giorgio M, Cicalese A, et al. A p53-p66 Shc signalling pathway controls intracellular redox status, levels of oxidation-damaged DNA and oxidative stress-induced apoptosis. Oncogene. 2002;21(24):3872-3878.

43. Ryter SW, Kim HP, Hoetzel A, et al. Mechanisms of cell death in oxidative stress. Antioxid Redox Signal. 2007;9(1):49-89.

44. Tapajós EC, Longo JP, Simioni AR, et al. In vitro photodynamic therapy on human oral keratinocytes using chloroaluminum-phthalocyanine. Oral Oncol. 2008;44(11):1073-1079.

45. Luo Y, Kessel D. Initiation of apoptosis versus necrosis by photodynamic therapy with chloroaluminum phthalocyanine. Photochem Photobiol. 1997;66(4):479-483.

46. Marchal S, Fadloun A, Maugain E, D'Hallewin MA, Guillemin F, Bezdetnaya L. Necrotic and apoptotic features of cell death in response to Foscan photosensitization of HT29 monolayer and multicell spheroids. Biochem Pharmacol. 2005;69(8):1167-1176.

47. Amaravadi RK, Thompson CB. The roles of therapy-induced autophagy and necrosis in cancer treatment. Clin Cancer Res. 2007;13(24):7271-7279.

48. Castano AP, Mroz P, Hamblin MR. Photodynamic therapy and antitumour immunity. Nat Rev Cancer. 2006;6(7):535-545.

49. Garg AD, Nowis D, Golab J, Agostinis P. Photodynamic therapy: illuminating the road from cell death towards anti-tumour immunity. Apoptosis. 2010;15(9):1050-1071.

50. Korbelik M, Stott B, Sun J. Photodynamic therapy-generated vaccines: relevance of tumour cell death expression. Br J Cancer. 2007;97(10): 1381-1387. 
International Journal of Nanomedicine

Dovepress

\section{Publish your work in this journal}

The International Journal of Nanomedicine is an international, peerreviewed journal focusing on the application of nanotechnology in diagnostics, therapeutics, and drug delivery systems throughou the biomedical field. This journal is indexed on PubMed Central, MedLine, CAS, SciSearch ${ }^{\circledR}$, Current Contents ${ }^{\circledR} /$ Clinical Medicine,
Journal Citation Reports/Science Edition, EMBase, Scopus and the Elsevier Bibliographic databases. The manuscript management system is completely online and includes a very quick and fair peer-review system, which is all easy to use. Visit http://www.dovepress.com/ testimonials.php to read real quotes from published authors.

Submit your manuscript here: http://www.dovepress.com/international-journal-of-nanomedicine-journal 